\title{
SNOWY OWL PREDATION ON A NORTHERN POCKET GOPHER: EVIDENCE OF NOCTURNAL FORAGING?
}

TERRY M. BREEN-SMITH and PAUL C. JAMES, Royal Saskatchewan Museum, 2340 Albert Street, Regina, Saskatchewan. S4P 3V7

The Snowy Owl is described as one of the most diurnal of all owl species. ${ }^{11}$ Such behaviour can be attributed to its breeding range north of the Arctic Circle where, during summer, daylight is continuous and its main prey is the lemming. ${ }^{5}$ Although it breeds at higher latitudes, the owl spends most of its lifetime wintering in southern Canada and the northern United States where it is a more catholic hunter. ${ }^{1,2,3}$ In southern Saskatchewan, Snowy Owls can be seen from early winter in most years when the first snow falls, but during the winter of 1993-94 they were sighted as early as mid-October, well before the first snow. Many of the first owls that were sighted were immature but these are often the ones to migrate first. ${ }^{6}$ Last year's early migration has been attributed to an apparent crash in the number of lemmings during the Arctic summer. During October and November several dead Snowy Owls were submitted to the Royal Saskatchewan Museum in Regina, and a larger number of injured ones to the Western College of Veterinary Medicine in Saskatoon. Many of these were very thin and weak (personal observations).

An immature male owl, aged and sexed using Josephson's criteria, was handed to the museum on Wednesday, 27 October 1993. ${ }^{7}$ It was found dead on a roadside near Balgonie, $18 \mathrm{~km}$ east of Regina. The bird only weighed $887 \mathrm{~g}$ which is very low; males usually average about $1,642 \mathrm{~g}$ (range $1,320-2,013 \mathrm{~g}$ ). ${ }^{4}$ Like the others that had been submitted to the museum, this bird had a severely protruding sternum with no overlying musculature indicating that the bird had been starving. It had obviously been killed quickly (from external examination its neck appeared to be fractured) because in its claws was evidence of its last foray, a Northern Pocket Gopher weighing $137 \mathrm{~g}, 15 \%$ of the bird's mass. The owl was killed with its prey well before the first of the permanent snow which started on 1 November.

Northern Pocket Gophers have been described as being strictly nocturnal and very rarely seen above ground, except for exceedingly unusual circumstances, and because of this they are "rarely the victims of predators." ${ }^{9,10,12}$ This is not to say that pocket gophers are not eaten by owls. For example, a Great Grey Owl broke through the thin roof of a digging gopher's tunnel and caught the inhabitant and later returned to catch three more that were attempting to plug the hole. ${ }^{12}$

The Snowy Owl's main prey in the winter on the prairie provinces where Northern Pocket Gophers exist, are 
White Footed Deer Mice, Meadow Voles and, to a lesser extent, Richardson's Ground Squirrels. ${ }^{3}$ Northern Pocket Gophers have rarely if ever been recorded in the diet of Snowy Owls.

To conclude, we believe that Snowy Owls may hunt at night more often than previously thought. It is possible that they need to do so during the colder, shorter days of winter in order to obtain enough to eat.

1. CAMPBELL, R.W. and MACCOLL, M.D. 1978. Winter foods of Snowy Owls in southwestern British Colombia. J. Wildl. Manage. 42:190-92.

2. BIRD, C.D. 1972. The Snowy Owl in the Calgary area, 1964-72. Calgary Field Naturalist 3:128-30.

3. BOXALL, P.C. and LEIN, M.R. 1982. Feeding ecology of Snowy Owls (Nyctea scandiaca) wintering in southern Alberta. Arctic 35:282-90.

4. EARHART, C. and JOHNSON, N.K. 1970. Size dimorphism and food habits of North American owls. Condor 72:251-64.

5. GABRIELSON, I.N. and LINCOLN, F.C. 1959. Birds of Alaska. Stackpole
Co., Harrisburg, PA, and Wild. Manage. Inst., Washington, DC.

6. JOHNSGARD, P.A. 1988. North American Owls. Smithsonian Institution.

7. JOSEPHSON, B. 1980. Aging and sexing Snowy Owls. J. Field. Ornith. 51:149-60.

8. KARALUS, K.E. and ECKERT, A.W. 1974. The owls of North America. Doubleday \& Company Inc. New York.

9. KOONZ, W.H. 1993. Northern Pocket Gophers above ground in winter. Blue Jay 51:124-25.

10. LEE, D.S. 1980. The pocket gopher mound probe. Natural History 80(6): 36-41.

11. PARMELEE, D.F. 1992. Snowy Owl. In: The birds of North America, No.10 (A. Poole, P. Stettenheim and F. Gill, Eds). Philadelphia: The Academy of Natural Sciences; Washington, D.C.: The American Ornithologists' Union.

12. TRYON, C.A. Jr. 1943. The Great Grey Owl as a predator on pocket gophers. Wils. Bull. 55:130-31.

13. WRIGLEY, R.E. 1986. Mammals in North America. Hyperion Press. Winnipeg, Manitoba.

A Pectoral Sandpiper, banded east of Saskatoon on 20 September 1961, was recovered in Yakutia, Russia, on 28 May 1963. In its lifetime it had probably migrated from eastern Russia through the Prairie Provinces to South America and back - at least twice. Houston \& Martinez. 1969. Bird-Banding 40:146. 